\title{
The effect of body condition score at calving and supplementation with Saccharomyces cerevisiae on milk production, metabolic status, and rumen fermentation of dairy cows in early lactation
}

\author{
R. M. Al Ibrahim, A. K. Kelly, L. O'Grady, V. P. Gath, C. McCarney, and F. J. Mulligan' \\ School of Agriculture, Food Science and Veterinary Medicine, University College Dublin, Belfield 4, Ireland
}

\begin{abstract}
The objective of this study was to examine the effects of live yeast (LY) supplementation and body condition score (BCS, 1-5 scale) at calving on milk production, metabolic status, and rumen physiology of postpartum (PP) dairy cows. Forty Holstein-Friesian dairy cows were randomly allocated to a $2 \times 2$ factorial design and blocked by yield, parity, BCS, and predicted calving date. Treatments were body condition at calving (low for BCS $\leq 3.5$ or high for BCS $\geq 3.75 ; \mathrm{n}=20$ ) and supplementation with LY (2.5 and $10 \mathrm{~g}$ of $\mathrm{LY} / \mathrm{d}$ per cow for pre- and postcalving, respectively; control, no LY supplementation; $\mathrm{n}=20$ ). The supplement contained $10^{9}$ cfu of Saccharomyces cerevisiae/g (YeaSacc $^{1026}$ TS, Alltech Inc., Nashville, TN). Daily milk yield, dry matter intake, milk composition, BCS, body weight, and backfat thickness were recorded. Blood samples were harvested for metabolite analysis on d 1 , 5, 15, 25, and 35 PP. Liver samples were harvested by biopsy for triacylglycerol (TAG) and glycogen analysis on d 7 precalving, and on d 7 and 21 PP. Rumen fluid was sampled by rumenocentesis for all cows on $\mathrm{d} 7$ and $21 \mathrm{PP}$. Supplementation with LY had no effect on milk yield, dry matter intake, rumen fluid $\mathrm{pH}$, or blood metabolites concentration of dairy cows with high or low BCS at calving. Feeding LY increased rumen acetate proportion and protozoal population, tended to increase liver glycogen, and decreased rumen ammonia nitrogen during early lactation. Over-conditioned cows at calving had greater body reserve mobilization and milk production and lower feed intake, whereas cows with a moderate BCS at calving had greater feed intake, lower concentrations of nonesterified fatty acids and $\beta$-hydroxybutyrate, lower liver TAG and TAG:glycogen ratio, and faster recovery from body condition loss. Additionally, the data suggest that concentrations of liver enzymes in blood might be used as an indicator for liver
\end{abstract}

Received February 24, 2010.

Accepted August 3, 2010.

${ }^{1}$ Corresponding author: finbar.mulligan@ucd.ie
TAG:glycogen ratio. Results indicate that in the case of this experiment, where the control treatment was associated with an acceptable rumen $\mathrm{pH}$, feeding yeast did not significantly improve indicators of energy status in dairy cows.

Key words: body condition score, dairy cow, metabolic status, Saccharomyces cerevisiae

\section{INTRODUCTION}

For dairy cattle, energy balance in the periparturient period has a direct influence on milk production, fertility, and susceptibility to metabolic and infectious disease (Mulligan and Doherty, 2008). The level of metabolic stress experienced by dairy cattle during their transition from late gestation to early lactation is often related directly to energy status pre- and postpartum (PP) (Mulligan et al., 2006). The reduction of DMI and the consequent negative energy balance in the periparturient period is often related to elevated body condition at calving and beforehand (Bines and Morant, 1983; Ingvartsen and Andersen, 2000). Previous works (Garnsworthy and Topps, 1982; Wathes et al., 2007) have shown that even small increases in the BCS of the dry cow at calving can lead to a reduction of energy status and feed intake in early lactation.

Different nutritional strategies aim to increase DMI and help avoid a negative energy balance and its consequences (McNamara et al., 2003; Friggens et al., 2004; Ingvartsen, 2006) during the early weeks of lactation. One such nutritional strategy is dietary supplementation with live yeast $(\mathbf{L Y})$, which has been found to improve DMI (Erasmus et al., 1992, Wohlt et al., 1998) in some cases. However, most of these studies have been performed on fistulated dry cows, steers, or even in vitro. Furthermore, few data exist on the effectiveness of LY supplementation on metabolic status in periparturient dairy cattle. Therefore, the objective of this study was to evaluate the effect of LY (Saccharomyces cerevisiae ${ }^{1026}$ ) supplementation on feed intake, milk production, body condition change, indicators of energy status, and rumen fermentation of periparturient dairy cows expected to have different levels of 
negative energy balance in early lactation as caused by differences in BCS at calving.

\section{MATERIALS AND METHODS}

\section{Animals and Experimental Design}

All procedures involving animals were approved by the University Animal Research Ethics Committee (University College Dublin) and conducted under experimental license from the Irish Department of Health and Children in accordance with the Cruelty to Animals Act 1876 and the European Communities (Amendment of Cruelty to Animals Act, 1876) Regulations (1994) for the use of live animals in experiments. Forty (10 primigravid and 30 multigravid) HolsteinFriesian dairy cows were housed in a common freestall facility for $21 \mathrm{~d}$ before their expected calving date until 70 DIM. Throughout this period, water was available ad libitum.

\section{Treatments and Feeding Management}

Cows were blocked by previous lactation 305-d milk yield, parity, BCS, and predicted calving date. Within each block, cows were randomly allocated to a $2 \times 2$ factorial arrangement of treatments approximately 60 $\mathrm{d}$ before parturition. Treatments were imposed from approximately d 14 precalving until d 70 of lactation. The main effects in this factorial experiment were 1) BCS (1-5 scale) at calving ( $\mathbf{L}$ for $\mathrm{BCS} \leq 3.5$ or $\mathbf{H}$ for BCS $\geq 3.75 ; \mathrm{n}=20$ ) and 2) feed supplementation with LY ( $\mathbf{Y}$ for supplemented or $\mathbf{C}$ for control; $\mathrm{n}=20$ ). The LY used was Yea-Sacc ${ }^{1026}$ TS (Alltech Inc., Nashville, TN), which was composed of live yeast cells from the strain S. cerevisiae ${ }^{1026}$ grown in batch cultures on a media of corn, molasses, malt, and trace minerals. The result is a concentrated mixture of live yeast cells and metabolites produced during growth. The product is carefully dried to maintain viability. Ingredient and chemical compositions of the feeds used are presented in Table 1. Body condition score was determined using a 5 -point scale $(1=$ emaciated, to $5=$ obese $)$ with quarter-point increments, functioning as a 17-point scale. Body condition scoring was always performed by the same trained operative by palpating and visualizing individual body parts of the spinal column (chine, loin, and rump), the cranial coccygeal vertebrae (tail head), the tuber ischia (pin bones), the tuber sacral (hip or hook bones), and the thigh region as described by Edmonson et al. (1989).

All groups were fed grass silage ad libitum for the entire 60-d dry period, and from $14 \mathrm{~d}$ precalving, each cow was supplemented with $2 \mathrm{~kg} / \mathrm{d}$ of a pre-calver concentrate containing thermo-stable LY $(2.5 \mathrm{~g} / \mathrm{d}$ per cow $\times 10^{9}$ cfu of $S$. cerevisiae/g) or $2 \mathrm{~kg} / \mathrm{d}$ of a control (without yeast) pre-calver concentrate. After calving, cows had ad libitum access to a forage mixture of $50 \%$ grass silage and $50 \%$ maize silage. Lactating cow concentrates were fed in the milking parlor twice daily beginning with $4 \mathrm{~kg} / \mathrm{d}$ per cow at calving and increasing stepwise by $0.5 \mathrm{~kg} / \mathrm{d}$ per cow until a full allocation of 8 $\mathrm{kg}$ of concentrate/d was reached. Concentrates for the Y group were supplemented with LY $(10 \mathrm{~g} / \mathrm{d}$ per cow $\times 10^{9}$ cfu of $S$. cerevisiae/g).

\section{Feed Sampling and Analyses}

Feed intake was monitored and recorded automatically from d 14 prepartum until d 70 PP for each animal using an automated feed intake recording system (Insentec B.V., Marknesse, the Netherlands). Concentrate feeding was controlled by the same system during the dry period and in the milking parlor for the milking cows. Samples of the prepartum and PP concentrates, maize, and grass silage were collected weekly and stored at $-20^{\circ} \mathrm{C}$ before analysis. Maize and grass silage DM were determined by oven drying at $55^{\circ} \mathrm{C}$ for $72 \mathrm{~h}$. Concentrate and dried maize and grass silage samples were milled through a 1-mm screen using a Christy and Norris hammer mill (Christy and Norris Process Engineers Ltd., Chelmsford, UK), dried at $105^{\circ} \mathrm{C}$ for a minimum of $16 \mathrm{~h}$ to determine the residual $\mathrm{DM}$ in the milled sample, and ashed at $550^{\circ} \mathrm{C}$ for $4 \mathrm{~h}$ in a muffle furnace (Nabertherm, Bremen, Germany) to determine the ash content. The $\mathrm{CP}$ content was determined as $\mathrm{N}$ $\times 6.25$ using a LECO FP-528 instrument (Leco Instrument Ltd., Cheshire, UK). The NDF and ADF content of feed were measured according to the procedures of Van Soest et al. (1991) using a Fibertec extraction unit (Tecator, Höganäs, Sweden) and heat-stable $\alpha$-amylase (Ankom Technology, Macedon, NY) to degrade starch in concentrate samples. The gross energy content of concentrate was determined using a Parr 1201 oxygen bomb calorimeter (Parr, Moline, IL). The ether extract was measured using a Soxtec instrument (Tecator). Silage $\mathrm{pH}$ was measured weekly in fresh samples using a Mettler Toledo MP $200 \mathrm{pH}$ meter (Mettler Toledo Ltd., Essex, UK). Determination of in vitro DM digestibility of grass silage samples was carried out using the procedure described by Tilley and Terry (1963). The starch content of maize silage was determined using the Megazyme total starch assay kit (Megazyme Int. Ireland Ltd., Wicklow, Ireland) according to AOAC (2001). Ammonia nitrogen $\left(\mathrm{NH}_{3}-\mathrm{N}\right)$ in grass silage was determined by a modification of the phenol/hypochlorite technique as described by O'Keefee and Sherrington (1983). 
Table 1. Ingredient and chemical composition of the concentrates used ( $\mathrm{g} / \mathrm{kg}$ of DM unless otherwise noted)

\begin{tabular}{|c|c|c|c|c|}
\hline \multirow[b]{2}{*}{ Item } & \multicolumn{2}{|c|}{ Prepartum } & \multicolumn{2}{|c|}{ Postpartum } \\
\hline & Control & Live yeast & Control & Live yeast \\
\hline \multicolumn{5}{|l|}{ Ingredient composition } \\
\hline Wheat & 421.3 & 421.2 & 300.3 & 300.3 \\
\hline Soy, $46 \%$ & - & - & 342.1 & 342.0 \\
\hline Double-zero rape, extracted & - & - & 100.1 & 100.1 \\
\hline Soy hulls & - & - & 98.1 & 96.5 \\
\hline Citrus pulp & - & - & 48.6 & 48.5 \\
\hline Corn gluten & 46.6 & 44.1 & - & - \\
\hline Palm kernel oil, expeller pressed & 88.7 & 88.7 & - & - \\
\hline Pollard & 157.8 & 157.8 & - & - \\
\hline African cotton, extracted & 136.6 & 136.6 & - & - \\
\hline Milk solids, extracted & 79.0 & 78.9 & 51.1 & 51.0 \\
\hline Crude palm oil & 6.5 & 6.5 & 10.2 & 10.2 \\
\hline Mono-dicalcium phosphate & - & - & 5.0 & 5.0 \\
\hline Lime flour & - & - & 8.4 & 7.2 \\
\hline Salt & 3.8 & 3.8 & 14.1 & 14.1 \\
\hline Calcium magnesium & 44.5 & 44.5 & 14.2 & 14.3 \\
\hline Vitamin E, 5\% & 10.7 & 10.7 & 2.0 & 2.0 \\
\hline Yea-Sacc T.S. $50 \%$ premix $^{1}$ & - & 2.7 & - & 2.8 \\
\hline Vitamin/trace element premix ${ }^{2}$ & 4.5 & 4.5 & 6.0 & 6.0 \\
\hline \multicolumn{5}{|l|}{ Chemical composition } \\
\hline $\mathrm{DM}$ & 882.6 & 887.2 & 874.6 & 883.3 \\
\hline Ash & 105.8 & 103.7 & 94.4 & 95.3 \\
\hline $\mathrm{CP}$ & 183.2 & 188.7 & 281.5 & 273.4 \\
\hline NDF & 250.7 & 262.1 & 203.4 & 202.4 \\
\hline $\mathrm{ADF}$ & 115.1 & 119.2 & 130.7 & 127.2 \\
\hline Starch & 299.2 & 297.5 & 183.9 & 182.2 \\
\hline Gross energy, MJ/kg of DM & 17.53 & 17.54 & 18.05 & 17.87 \\
\hline Ether extract & 24.5 & 23.0 & 23.0 & 23.4 \\
\hline
\end{tabular}

${ }^{1}$ Alltech Inc. (Lexington, KY).

${ }^{2}$ Contains in prepartum concentrate (DM basis): vitamin A, 8,500 IU $/ \mathrm{kg}$; vitamin $\mathrm{D}_{3}, 2,400 \mathrm{IU} / \mathrm{kg}$; vitamin E, $500 \mathrm{IU} / \mathrm{kg}$; magnesium, 2.20\%; copper, $142 \mathrm{mg} / \mathrm{kg}$ (as Cu sulfate); copper, $40 \mathrm{mg} / \mathrm{kg}$ (as Cu chelate of AA); selenium, $2.9 \mathrm{mg} / \mathrm{kg}$ (as Na selenite); iodine, $31 \mathrm{mg} / \mathrm{kg}$ (as Ca iodate). Contains in postpartum concentrate (DM basis): vitamin A, 7,000 IU $/ \mathrm{kg}$; vitamin $\mathrm{D}_{3}, 2,000 \mathrm{IU} / \mathrm{kg}$; vitamin E, $100 \mathrm{IU} / \mathrm{kg}$; magnesium, 0.85\%; copper, $37 \mathrm{mg} / \mathrm{kg}$ (as Cu sulfate); copper, $15 \mathrm{mg} / \mathrm{kg}$ (as Cu chelate of AA); selenium, $0.65 \mathrm{mg} / \mathrm{kg}$ (as Na selenite); iodine, $10 \mathrm{mg} / \mathrm{kg}$ (as Ca iodate).

\section{Milk Measurements and Components}

Cows were milked twice daily at 0700 and $1500 \mathrm{~h}$, and milk yield was recorded individually. Milk samples were collected weekly at consecutive 0700 and 1500 $\mathrm{h}$ milkings, and samples were pooled in proportion to their 0700 and 1500 yield. These composite milk samples were kept preserved (Broad Spectrum Microtabs, D\&F Control Systems, Inc., Norwood, MA) and refrigerated until analyzed for fat, protein, lactose, and SCC by near-infrared spectrophotometry (MilkoScan, Foss, Hillerød, Denmark). Solids-corrected milk yield was calculated by using the equation of Tyrrell and Reid (1965), where SCM, $\mathrm{kg}=12.3$ fat, $\mathrm{kg}+6.56 \times$ $\mathrm{SNF}, \mathrm{kg}-0.0752 \times$ milk yield, $\mathrm{kg}$.

\section{Ultrasonography, BCS, and BW}

Backfat and muscle ultrasonography, body condition scoring, and body weighing were performed individu- ally to determine body reserves and nutritional status of cows in all treatments. Cows were ultrasonographically scanned to obtain longissimus dorsi (eye muscle) depth and backfat thickness using a Dynamic Imaging Ultrasound Scanner (Concept MLV with a $3.5-\mathrm{MHz}$ transducer, Dynamic Imaging Ltd., Livingston, UK). Ultrasonography was carried out at calving and every $14 \mathrm{~d}$ until d 56 PP. The depth of $\mathrm{m}$. longissimus dorsi (muscle depth, MD) was measured at the third lumbar vertebra, where depth of this muscle is greatest. Measurement was from the bottom of the backfat layer to the top of the bone. Three fat-depth measurements were taken at the third lumbar vertebra (lumbar fat depth, LFD), and a further 4 were taken at the rump (rump fat depth, RFD) as described by Robinson et al. (1992). The rump site is over the gluteus muscle on the rump, at the intersection of a line through the pin bone parallel to the chine and its perpendicular line through the third sacral crest. Lumbar and RFD were calculated as the mean of the values recorded. 
Body condition score and BW were assessed weekly starting at calving until $70 \mathrm{~d}$ PP following the morning milking. Body weight was measured using a calibrated electronic scale (Tru-Test Ltd., Auckland, New Zealand). The scale was calibrated weekly with known weights. The loss in BCS and BW from calving to nadir, and weeks PP corresponding to nadir BCS or nadir BW were retained for each individual cow. Weeks PP to nadir BCS and to nadir BW were also determined. Nadir BCS and BW were the first lower PP records immediately followed by 2 higher consecutive values.

\section{Rumen Fluid Sampling and Analyses}

Rumen fluid (RF) samples were taken on d 7 and $21 \mathrm{PP}$ from all 40 cows by rumenocentesis after $4 \mathrm{~h}$ of concentrate feeding to determine rumen $\mathrm{pH}$, concentrations of $\mathrm{NH}_{3}-\mathrm{N}, \mathrm{VFA}$, and lactic acid, and to perform a protozoal count. Rumenocentesis was conducted as described by Nordlund and Garrett (1994) using a 14-gauge, 130-mm-long disposable stainless-steel needle and a $20-\mathrm{mL}$ syringe. When a sufficient volume of $\mathrm{RF}$ was obtained, air was evacuated from the syringe and $\mathrm{pH}$ was immediately determined with a Mettler Toledo MP $200 \mathrm{pH}$ meter. A 10-mL sample of RF was added to $0.25 \mathrm{~mL}$ of $9.0 \mathrm{M} \mathrm{H}_{2} \mathrm{SO}_{4}$ in a universal container for subsequent $\mathrm{NH}_{3}-\mathrm{N}$ analysis. An additional $10 \mathrm{~mL}$ of $\mathrm{RF}$ was preserved in $0.5 \mathrm{~mL}$ of $70 \mathrm{mM} \mathrm{HgCl}$ in a ratio of 1:20 preservative solution:RF and subsequently used for determination of VFA concentrations. Samples were stored at $-20^{\circ} \mathrm{C}$ pending analysis. A 1-mL sample of RF was added to $9 \mathrm{~mL}$ of methyl green solution and stored in darkness according to the method of Jordan et al. (2006) for subsequent protozoal enumeration.

The relative molar concentrations of VFA (acetic, propionic, butyric, isobutyric, isovaleric, and valeric acids) in RF were determined by GLC according to the method of Porter and Murray (2001). An additional $4 \mathrm{~mL}$ of $\mathrm{RF}$ were stored at $-20^{\circ} \mathrm{C}$ for later analysis of lactate using an enzymatic assay procedure (Testcombination L-lactic acid/D-lactic acid kit, R-Biopharm AG, Darmstadt, Germany) as described by Goodall and Byers (1978). Rumen ciliate protozoa numbers were determined using a 0.1-mm-depth Bürker counting chamber (Rudolf Brand, Wertheim, Germany), with duplicate counts carried out for each sample. The concentration of rumen $\mathrm{NH}_{3}-\mathrm{N}$ in the $\mathrm{RF}$ was determined by the colorimetric technique as described by Chaney and Marbach (1962). Total colony forming units per kilogram of precalving and lactating cow compound was assayed on a pooled feed sample according to the European Committee for Standardization (2008).

\section{Liver Sampling and Analyses}

Percutaneous liver biopsy samples (about $400 \mathrm{mg}$ ) were obtained on approximately d 7 precalving, and $\mathrm{d} 7$ and $21 \mathrm{PP}$ for the analysis of glycogen and triacylglycerol (TAG). The biopsy technique was adapted from Grohn and Lindberg (1982). Liver samples were immediately stored at $-20^{\circ} \mathrm{C}$ until analyzed. Liver TAG concentrations were assayed according to the manufacturer's protocol using the colorimetric triglyceride quantification kit (K622-100, BioVision, Mountain View, CA). Liver glycogen concentrations were determined by digestion of the tissue in hot $30 \%$ potassium hydroxide (wt/vol), and quantification of glycogen by the anthrone reaction was as described by Carroll et al. (1956).

\section{Blood Sampling and Analyses}

Blood samples $(10 \mathrm{~mL})$ were collected by jugular venipuncture from each cow at 14 and $7 \mathrm{~d}$ to expected calving date and on d 1, 5, 15, 25, and $35 \mathrm{PP}$. Blood was collected into two 10-mL plain evacuated serum tubes for NEFA, BHBA, Ca, Mg, P, $\gamma$-glutamyl transferase (GGT), glutamate dehydrogenase (GLDH), and total bilirubin (BIL) analysis, and one 5-mL evacuated tube containing potassium oxylate-sodium fluoride as a glycolytic inhibitor for glucose analysis (BD gray-topped tube, Vacutainer Systems, Preanalytical Solutions, Plymouth, UK). Serum was separated by centrifugation at $1,600 \times g$ at $4^{\circ} \mathrm{C}$ for $15 \mathrm{~min}$ and stored frozen at $-20^{\circ} \mathrm{C}$ until assayed for glucose, NEFA, BHBA, Ca, $\mathrm{Mg}, \mathrm{P}, \mathrm{GGT}, \mathrm{GLDH}$, and BIL concentrations with commercial biochemical assay kits (Boehringer Mannheim, Mannheim, Germany, and Randox Private Ltd., Crumlin, UK) on an automated biochemical analyzer (ABX Mira, Horiba Medical, Montpellier, France).

\section{Statistical Analyses}

Data were checked for adherence to the normal distribution and homogeneity of variance using histograms and formal statistical tests as part of the UNIVARIATE procedure in SAS Institute (2004). The natural logarithm transformation of rumen protozoal counts, milk SCC, GGT, GLDH, BIL, BHBA, lactic acid, and RF propionate were used to normalize the distributions as preliminary analyses revealed that the distribution of values for these analyses was positively skewed. The transformed data were used to calculate $P$-values. However, the corresponding least squares means and standard errors of the non-transformed data are presented in results for clarity. Data were analyzed 
Table 2. Effect of live yeast culture supplementation (Saccharomyces cereviciae ${ }^{1026}$ ) and BCS at calving on DMI, milk yield and composition, BCS, BW, and backfat and muscle thickness of early lactation dairy cows

\begin{tabular}{|c|c|c|c|c|c|c|c|c|c|c|c|}
\hline \multirow[b]{2}{*}{ Item $^{1}$} & \multicolumn{3}{|c|}{ LY supplementation ${ }^{2}$} & \multicolumn{3}{|c|}{ BCS at calving ${ }^{3}$} & \multicolumn{5}{|c|}{ Significance } \\
\hline & $\mathrm{C}$ & $\mathrm{Y}$ & $\mathrm{SED}^{4}$ & $\mathrm{H}$ & $\mathrm{L}$ & SED & LY & BCS & $\mathrm{W}^{5}$ & $\mathrm{LY} \times \mathrm{W}$ & $\mathrm{BCS} \times \mathrm{W}$ \\
\hline Milk, kg/cow per d & 27.90 & 28.71 & 1.29 & 29.73 & 26.88 & 1.32 & NS & $*$ & $* *$ & NS & NS \\
\hline $\mathrm{SCM}, \mathrm{kg} /$ cow per $\mathrm{d}$ & 26.59 & 27.58 & 1.15 & 28.41 & 25.77 & 1.17 & NS & * & $* *$ & NS & * \\
\hline Fat, $\%$ & 4.21 & 4.36 & 0.10 & 4.28 & 4.28 & 0.10 & NS & NS & NS & $*$ & NS \\
\hline Protein, \% & 3.15 & 3.09 & 0.07 & 3.07 & 3.18 & 0.07 & NS & NS & $* *$ & NS & NS \\
\hline BCS loss/wk & 0.86 & 0.86 & 0.10 & 1.08 & 0.64 & 0.10 & NS & $* *$ & & & \\
\hline wnBCS & 4.16 & 3.49 & 0.63 & 4.41 & 3.24 & 0.64 & NS & $t$ & & & \\
\hline $\mathrm{BW}, \mathrm{kg}$ & 612.7 & 605.8 & 17.5 & 636.4 & 582.1 & 17.9 & NS & $* *$ & $* *$ & NS & $\dagger$ \\
\hline BW loss/wk, kg & 43.95 & 45.20 & 5.08 & 52.15 & 37.00 & 5.18 & NS & ** & & & \\
\hline wnBW & 4.06 & 3.58 & 0.59 & 4.51 & 3.13 & 0.60 & NS & * & & & \\
\hline $\mathrm{RFD}, \mathrm{mm}$ & 3.76 & 4.26 & 1.02 & 5.61 & 2.41 & 1.04 & NS & ** & $* *$ & NS & ** \\
\hline $\mathrm{LFD}, \mathrm{mm}$ & 2.82 & 2.75 & 0.74 & 3.60 & 1.98 & 0.75 & NS & $*$ & $* *$ & NS & ** \\
\hline
\end{tabular}

${ }^{1}{ }_{\mathrm{wnBCS}}=$ time $(\mathrm{wk}, 1-10$ postpartum) to nadir BCS; wnBW = time (week, $1-10$ postpartum) to nadir BW; RFD = rump fat depth; LFD = lumbar fat depth; MD = muscle (longissimus dorsi) depth.

${ }^{2} \mathrm{LY}$ supplementation $=$ live yeast culture supplementation; $\mathrm{C}=$ control; $\mathrm{Y}=$ supplemented.

${ }^{3} \mathrm{BCS}$ at calving: $\mathrm{H}=$ high $\mathrm{BCS}$ at calving; $\mathrm{L}=$ low $\mathrm{BCS}$ at calving.

${ }^{4} \mathrm{SED}=$ standard error of differences

${ }^{5} \mathrm{~W}=$ time effect (wk $1-10$ postpartum).

$\dagger P<0.10 ; * P<0.05 ;{ }^{* *} P<0.01$.

using PROC MIXED for repeated measures with terms for BCS, LY supplementation, block, time period, and their interactions included in the statistical model. Cow was the repeated subject and was modeled as a random effect. Actual calving day and the length of time on the precalving diet were used as covariates. The compound symmetry, unstructured, first-order autoregressive, and Toeplitz variance-covariance structures were tested and the most appropriate (lowest Akaike's information criterion, Akaike's information criterion with correction, and Bayesian information criterion values) was used for each analysis. The existence of a statistically significant difference between least squares means was tested by the PDIFF command incorporating the Tukey test for pairwise comparison of treatment means. The REG procedure was used for linear regression. Change in LFD, RFD, and MD for each individual cow during the test period was analyzed as the coefficient of the linear regression of measurements upon time (d) using the REG procedure. No significant $(P>0.10) 2$-way $(\mathrm{BCS} \times \mathrm{LY})$ or 3 -way $(\mathrm{BCS} \times \mathrm{LY} \times$ time $)$ interactions were found for any of the measured variables and these were therefore excluded from the dataset. As a result, the main effects of BCS and LY were presented separately. For all the statistical analyses, no effects were declared at $P \geq 0.10$, trends at $0.05 \leq P<0.10$, and differences at $P<0.05$. Results are presented as least squares means \pm standard error of mean unless otherwise stated.

\section{RESULTS AND DISCUSSION}

\section{DMI, Milk Yield, and Composition}

Supplementation with LY had no effect $(P>0.10)$ on DMI, milk yield, or SCM during the whole experimental period (Table 2), but milk fat concentration of the $\mathrm{Y}$ group was greater than for the $\mathrm{C}$ group in wk $2 \mathrm{PP}$ $(P=0.005 ; 4.70$ vs. $4.09 \pm 0.15$ respectively) and in wk $3 \mathrm{PP}(P=0.005 ; 4.78$ vs. $4.18 \pm 0.15$, respectively $)$. A $\mathrm{LY} \times$ time interaction $(P<0.05)$ was observed for milk fat percentage. Cows in the L group had greater $(P<$ $0.05)$ DMI and lower $(P<0.05)$ milk yield and SCM than cows in the $\mathrm{H}$ group for the whole $\mathrm{PP}$ period. A time effect $(P<0.01)$ on DMI and a tendency $(P=$ $0.06)$ of BCS $\times$ time interaction on DMI were found.

Many studies have reported that feeding LY does not increase DMI pre- and postcalving, nor does it increase milk yield of early lactation Holstein dairy cows (Soder and Holden, 1999; Wang et al., 2001). However, in some cases, higher DMI and milk yield has been observed following S. cerevisiae supplementation (Wohlt et al., 
1991, 1998). Several factors affect the response of dairy cows to LY supplementation, such as the type of forage given, the forage:concentrate ratio (Piva et al., 1993), stage of lactation (Erasmus et al., 1992; Dawson, 1993), and yeast strain and viability (Newbold et al., 1995; Alshaikh et al., 2002; Chaucheyras-Durand et al., 2008). Researchers have suggested that live yeasts are metabolically active in the rumen, at least for a short time (Kung et al., 1997), thereby modifying ruminal fermentation and stimulating microbial growth (Dawson et al., 1990; Erasmus et al., 2005). Such changes are often associated with increased dietary fiber digestibility (Guedes et al., 2008), which could increase rate of passage and therefore improve DMI, productivity, or both. In the current study, the effects of LY on rumen fermentation parameters were modest and it is not surprising that DMI did not increase. Other reasons for the lack of effect of LY supplementation in this work may include the relatively high rumen $\mathrm{pH}$ observed in the control group, which may have worked against finding any positive effect of the supplement (Yoon and Stern, 1996; Enjalbert et al., 1999) or possibly reduced viability of the product during the course of the trial in the commercial production environment used. The colony-forming units count in the precalving and lactating cow compound indicated levels of 4.5 and $6.0 \times$ $10^{8} \mathrm{cfu} / \mathrm{kg}$, respectively.

The effect of body condition at calving on DMI and milk yield has been well investigated by numerous studies (Stockdale, 2001, 2004; Hayirli et al., 2002). Hayirli et al. (2002) suggested that a lack of mobile fat reserves force thin cows at calving to meet nutrient demands by increasing DMI. The effect of over-conditioning on the DMI depression reported in the current study is consistent with the findings of Grainger et al. (1982) and Hayirli et al. (2002), who reported a linear reduction in DMI immediately after calving as BCS increased. In addition, the higher milk yield and SCM in the $\mathrm{H}$ group reported here are in agreement with the results of Stockdale (2004), who pointed out that in early lactation, milk production increases linearly as BCS at calving increases, by $1.0 \mathrm{~kg}$ of milk/unit of body condition (on the 8-point scale) per day. In herds where a 365-d calving interval is desired and where moderate milk production is acceptable (e.g., in grazing systems), a moderate BCS at calving may be appropriate to ensure DMI is maximized in early lactation.

\section{BCS, BW, and Scanning Measurements}

No effect $(P>0.10)$ of LY supplementation was found on BCS, BW, loss in body condition, backfat and muscle depth, or loss of backfat and muscle (Table 2). At parturition, the BCS of the $\mathrm{H}$ and $\mathrm{L}$ groups averaged 4.18 and $3.30 \pm 0.09$ units, respectively $(P$ $<0.01$ ), and the BW of the $\mathrm{H}$ and $\mathrm{L}$ groups averaged 667.8 and $604.3 \pm 14.3 \mathrm{~kg}$, respectively $(P<0.01)$. A BCS $\times$ time interaction $(P<0.01)$ was observed on $\mathrm{BCS}$ and BW for the whole experimental period, and cows in the $\mathrm{L}$ group tended $(P<0.10)$ to reach BCS nadir and reached $(P<0.05)$ BW nadir sooner, losing less $(P<0.01)$ BCS and BW $(P<0.01)$ than did cows in the $\mathrm{H}$ group (Table 2). The significant differences in BCS and BW between the $\mathrm{H}$ and $\mathrm{L}$ groups in the early PP period started to disappear from wk $6 \mathrm{PP}$, and cows in the $\mathrm{L}$ groups started to gain $\mathrm{BCS}$ and $\mathrm{BW}$ from wk 4 PP. Consistently at calving, MD was 47.07 and $40.50 \mathrm{~mm}(P<0.01)$, RFD was 9.80 and $4.09 \mathrm{~mm}$ $(P<0.01)$, and LFD was 5.92 and $2.96 \mathrm{~mm}(P<0.01)$ for the $\mathrm{H}$ and $\mathrm{L}$ groups, respectively. After parturition, the change in RFD and LFD was influenced by BCS at calving, and the loss in RFD and LFD of the H group was greater $(P<0.01)$ than for the $\mathrm{L}$ group (Table $2)$. However, no differences $(P>0.10)$ in the change in MD were found for the $\mathrm{H}$ and $\mathrm{L}$ groups during the experimental period. A BCS $\times$ time interaction $(P<$ 0.01 ) was observed on MD, RFD, and LFD (Table 2). Differences in MD, LFD, and RFD in the early PP period between the $\mathrm{H}$ and $\mathrm{L}$ groups disappeared $(P>$ $0.10)$ on wk $8 \mathrm{PP}$, and cows in the L group started to gain MD from wk $6 \mathrm{PP}$.

The lack of significance of LY supplementation on $\mathrm{BCS}, \mathrm{BW}$, and the changes in BCS and BW reported in the current study, also has been demonstrated in recent studies (Lehloenya et al., 2008). This lack of LY supplementation effect on BCS and BW may be due to the lack of effect of LY on DMI. The interaction between the effect of BCS at calving and time (d) on MD, RFD, and LFD may be explained by the more rapid decreases of muscle and fat thickness in $\mathrm{H}$ versus $\mathrm{L}$ groups, and the faster recovery of $\mathrm{L}$ group in muscle and fat depth. The L group gained MD at d $42 \mathrm{PP}$, whereas the $\mathrm{H}$ group was still losing MD at this point. These results are in agreement with those of Kokkonen et al. (2005), who found that fatter cows lost subcutaneous fat more rapidly than did thin cows from wk 1 precalving to wk 4 PP. Similarly, Hammon et al. (2009) reported that fatter cows showed much greater backfat loss than did lean cows.

\section{Blood Metabolites and Liver Variables}

No differences $(P>0.10)$ existed in serum metabolite concentrations between the $\mathrm{Y}$ and $\mathrm{C}$ groups. Interactions between the effect of BCS at calving and time $(P$ $<0.01$ ) were observed for NEFA, BHBA, glucose, and BIL concentrations, and cows with high body condition at calving had higher $(P<0.01)$ NEFA, BHBA, and 
Table 3. Effect of live yeast culture supplementation (Saccharomyces cereviciae ${ }^{1026}$ ) and BCS at calving on blood metabolites, enzymes, liver glycogen, and triacylglyceride of dairy cows

\begin{tabular}{|c|c|c|c|c|c|c|c|c|c|c|c|}
\hline Item $^{1}$ & \multicolumn{3}{|c|}{ LY supplementation ${ }^{2}$} & \multicolumn{3}{|c|}{ BCS at calving $^{3}$} & \multicolumn{5}{|c|}{ Significance } \\
\hline Magnesium, mmol/L & 0.92 & 0.93 & 0.02 & 0.94 & 0.92 & 0.02 & $\mathrm{NS}$ & NS & $* *$ & NS & NS \\
\hline Phosphorus, $\mathrm{mmol} / \mathrm{L}$ & 1.39 & 1.47 & 0.05 & 1.40 & 1.47 & 0.05 & $t$ & $t$ & $* *$ & NS & NS \\
\hline Glucose, mmol/L & 3.52 & 3.51 & 0.06 & 3.44 & 3.59 & 0.06 & NS & $* *$ & $* *$ & NS & ** \\
\hline $\mathrm{NEFA}, \mathrm{mmol} / \mathrm{L}$ & 0.50 & 0.47 & 0.05 & 0.56 & 0.40 & 0.05 & NS & $* *$ & $* *$ & NS & $* *$ \\
\hline GLDH, U/L & 9.72 & 9.08 & 0.13 & 9.70 & 9.11 & 0.13 & NS & NS & $* *$ & NS & NS \\
\hline $\mathrm{BIL}, \mu \mathrm{mol} / \mathrm{L}$ & 7.92 & 7.75 & 0.06 & 8.70 & 7.0 & 0.06 & NS & $* *$ & ** & NS & $* *$ \\
\hline Glycogen mmol glucose/g of wet liver & 0.15 & 0.16 & 0.01 & 0.14 & 0.17 & 0.01 & $\dagger$ & $*$ & $* *$ & NS & $*$ \\
\hline TAG, $\mathrm{mg} / \mathrm{g}$ of wet liver & 51.02 & 49.53 & 1.26 & 68.57 & 31.98 & 1.28 & NS & $* *$ & $* *$ & NS & ** \\
\hline TAG:Glycogen ratio & 0.80 & 0.68 & 0.156 & 1.14 & 0.33 & 0.156 & NS & ** & $* *$ & NS & $* *$ \\
\hline
\end{tabular}

${ }^{1} \mathrm{BHBA}=\beta$-hydroxybutyrate (level of significance corresponds to transformed variable); GGT $=\gamma$-glutamyl transferase (level of significance corresponds to transformed variable); GLDH $=$ glutamate dehydrogenase (level of significance corresponds to transformed variable); BIL $=$ total bilirubin (level of significance corresponds to transformed variable); $\mathrm{TAG}=$ triacylglyceride concentration.

${ }^{2} \mathrm{LY}$ supplementation $=$ live yeast culture supplementation; $\mathrm{C}=$ control; $\mathrm{Y}=$ supplemented.

${ }^{3} \mathrm{BCS}$ at calving: $\mathrm{H}=$ high $\mathrm{BCS}$ at calving; $\mathrm{L}=$ low $\mathrm{BCS}$ at calving.

${ }^{4} \mathrm{SED}=$ standard error of differences.

${ }^{5} \mathrm{D}=$ time effect $(\mathrm{d} 1,5,15,25$, and 35 postpartum for blood variables, and d 7 prepartum, $\mathrm{d} 7$ and 21 postpartum for liver variables).

$\dagger P<0.10 ;{ }^{*} P<0.05 ;{ }^{* *} P<0.01$.

BIL and lower $(P<0.05)$ glucose concentrations than did cows with low body condition at calving (Table 3). The activity of GGT and GLDH enzymes was not affected $(P>0.10)$ by LY supplementation or BCS at calving. Liver glycogen concentration tended to be higher $(P<0.10)$ in the $\mathrm{Y}$ versus $\mathrm{C}$ group and higher $(P<0.05)$ in the $\mathrm{L}$ versus $\mathrm{H}$ group during the overall experimental period. However, on d 7 prepartum, no differences $(P>0.10)$ were detected in liver glycogen concentrations between the $\mathrm{C}$ and $\mathrm{Y}$ groups ( 0.26 vs. $0.28 \pm 0.01 \mathrm{mmol}$ of glucose/g of wet liver, respectively) or between $\mathrm{H}$ and $\mathrm{L}$ groups ( 0.27 vs. $0.26 \pm 0.01 \mathrm{mmol}$ of glucose/g of wet liver, respectively). Furthermore, concentrations of glycogen were different $(P=0.01)$ between the $\mathrm{H}$ and $\mathrm{L}$ groups at $\mathrm{d} 7$ and $21 \mathrm{PP}(0.057$ vs. $0.096 \pm 0.01$ and 0.101 vs. $0.138 \pm 0.01 \mathrm{mmol}$ of glucose/g of wet liver, respectively). A tendency ( $P$ $=0.06$ ) for a higher glycogen concentration in the $\mathrm{Y}$ versus $\mathrm{C}$ group at $\mathrm{d} 7 \mathrm{PP}$ was detected, averaging 0.091 versus $0.062 \pm 0.01 \mathrm{mmol}$ of glucose $/ \mathrm{g}$ of wet liver, respectively. Triacylglyceride concentration was influenced by BCS at calving $(P<0.01)$, but not by LY supplementation $(P>0.10)$. At d 7 prepartum, TAG concentration was not different $(P>0.10)$ between the $\mathrm{H}$ and $\mathrm{L}$ groups, whereas at $\mathrm{d} 7$ and $21 \mathrm{PP}$, differences were observed between the $\mathrm{H}$ and $\mathrm{L}$ groups $(P<0.01$; 93.23 vs. $39.56 \pm 1.7 \mathrm{mg} / \mathrm{g}$ of wet liver for $\mathrm{d} 7 \mathrm{PP}$, and $P<0.01 ; 91.57$ vs. $38.53 \pm 1.7 \mathrm{mg} / \mathrm{g}$ of wet liver for d $21 \mathrm{PP})$. The ratio of TAG:glycogen concentrations was higher $(P<0.01)$ in $\mathrm{H}$ versus $\mathrm{L}$ groups with no effect of LY supplementation $(P>0.10)$ during the overall tested period. There was an interaction $(P<$ 0.01 ) between the effect of BCS at calving and time (days related to calving) on TAG:glycogen ratio. This ratio was not different $(P>0.10)$ between $\mathrm{H}$ and $\mathrm{L}$ groups at d 7 prepartum, whereas it was different $(P<$ $0.01)$ at $\mathrm{d} 7 \mathrm{PP}(2.29$ vs. $0.58 \pm 0.15)$ and at $\mathrm{d} 21 \mathrm{PP}$ (1.03 vs. $0.34 \pm 0.15)$.

When data were pooled across treatments, a negative relationship was observed between GGT activity at d $25 \mathrm{PP}$ and liver glycogen concentration at d $21 \mathrm{PP}$ $\left(\mathrm{r}^{2}=0.21, P=0.008\right)$, whereas positive relationships between GGT activity and liver TAG concentration at d $21 \mathrm{PP}\left(\mathrm{r}^{2}=0.30, P=0.001\right)$ and TAG:glycogen ratio at d $21 \mathrm{PP}\left(\mathrm{r}^{2}=0.34, P=0.0004\right)$ were observed. Likewise, BIL serum concentrations at d $25 \mathrm{PP}$ were negatively related to liver glycogen concentrations at d $21 \mathrm{PP}\left(\mathrm{r}^{2}=0.47, P<0.0001\right)$ and positively related to liver TAG concentrations at d $21 \mathrm{PP}\left(\mathrm{r}^{2}=0.55, P\right.$ $<0.0001)$ and to TAG:glycogen ratio at d $21 \mathrm{PP}\left(\mathrm{r}^{2}=\right.$ $0.64, P<0.0001)$.

The analyses of blood metabolite concentration and liver glycogen and triglyceride were performed to enable more sensitive measurements of energy status and to gain further insight into metabolic status. The lack of significance in the effect of LY supplementation on NEFA, BHBA, glucose, and liver TAG found in the present study likely reflects the lack of improvement in DMI, and hence BCS and energy balance in the supplemented group. The higher NEFA concentrations in the $\mathrm{H}$ group agree with results found in previous studies (Kokkonen et al., 2005; Hammon et al., 2009). This 
indicates that, compared with cows in the L group, over-conditioned cows (H group) initiated more extensive body fat mobilization during the early PP period. The higher BHBA concentrations in the $\mathrm{H}$ group may indicate enhanced ketogenesis, a result that is in agreement with Kokkonen et al. (2005) and Hammon et al. (2009), who found the plasma concentrations of BHBA of fatter cows to be higher than leaner cows. The higher BHBA, NEFA, and liver TAG, and lower glucose concentrations coincided with higher BCS and BW loss in the $\mathrm{H}$ group, which suggests that the over-conditioned cows had a greater energy deficit and have been more likely to develop excessive fat accumulation in the liver during early lactation (Kunz et al., 1985; Ohgi et al., 2005). This was in agreement with Gillund et al. (2001), who found that a cow with a BCS $\geq 3.5$ at calving was approximately 2.5 times more likely to become ketotic than cows with scores at calving $\leq 3.25$. Drackley et al. (1992) suggested that a liver TAG:glycogen ratio from 1.5 to 2 during early lactation might indicate a greater susceptibility to clinical ketosis and hepatic lipidosis. In our study, over-conditioned cows in the $\mathrm{H}$ group had a TAG:glycogen ratio at $\mathrm{d} 7$ and $21 \mathrm{PP}$ of 2.3 and 1.03 \pm 0.15 , respectively, which was higher $(P>0.05)$ than for cows in the moderate body condition (L) group. Accordingly, over-conditioned cows in the present study may have been at greater risk of developing clinical ketosis and fatty liver at d $7 \mathrm{PP}$ but not at d $21 \mathrm{PP}$, indicating that these cows had moderately fatty livers.

It has been reported that increased liver enzyme activity may be related to the severity of fatty liver and hepatocyte damage (Feinstein et al., 1993; Ohtsuka et al., 2001). In general, the activities of liver enzymes are reported to be temporarily elevated during the transition period not as pathological condition, but rather as an adjustment of hepatocyte turnover rate to increased metabolic demands during late gestation and early lactation (Hoedemaker et al., 2004). This may explain the effect of time on the activities of liver enzymes reported here. Busato et al. (2002) reported that this development was not influenced by body condition, and enzymes activity levels were within normal ranges in all groups (Blood and Radostits, 1989). The relationships between liver enzymes in serum and liver TAG, glycogen, and TAG:glycogen ratio were significant and did reflect the degree of fatty infiltration in the liver in early lactation. Therefore, concentrations of liver enzymes in blood may be used to assess the severity of fatty liver in early lactation.

\section{Rumen Fermentation}

Mean ruminal $\mathrm{pH}$ and lactic acid were not influenced $(P>0.10)$ by LY supplementation, whereas rumen
$\mathrm{NH}_{3}-\mathrm{N}$ concentration was higher $(P<0.05)$ in the $\mathrm{C}$ versus Y group (Table 4$)$. Higher $(P<0.05)$ protozoal counts were recorded in the $\mathrm{Y}$ versus $\mathrm{C}$ group (240 vs. $222 \pm 5.08, \times 10^{3} / \mathrm{mL}$, respectively). Furthermore, relative molar concentrations of acetate tended to be higher $(P<0.10)$ in the $\mathrm{Y}$ versus $\mathrm{C}$ group. The ruminal $\mathrm{pH}$ of the control group remained above 6.0 (Table 4 ), suggesting that cows in the control group were unlikely to have been at risk of ruminal acidosis. Previous studies reported that under such circumstances, when ruminal $\mathrm{pH}$ of control cows was higher than 6.0, LY supplementation had little or no effect on ruminal pH (Yoon and Stern, 1996; Doreau and Jouany, 1998; Enjalbert et al., 1999). This may explain the lack of significance in the effect of LY supplementation on ruminal $\mathrm{pH}$ and lactic acid concentration reported here and in previous studies (Putnam et al., 1997; Erasmus et al., 1992, 2005). Thus, in the case of this experiment, the opportunity to enhance fiber digestion and increase DMI did not arise because of the high rumen $\mathrm{pH}$ in the control group. However, these data must be viewed in the context of only 2 rumen samples per cow collected by rumenocentesis.

The lower rumen $\mathrm{NH}_{3}-\mathrm{N}$ concentrations in the rumen fluid of the LY-supplemented group reported in the current study are in line with results from some previous reports (Erasmus et al., 1992; Marden et al., 2008; Moallem et al., 2009), but not with others (Doreau and Jouany, 1998; Guedes et al., 2008; Thrune et al., 2009) who found no effect of LY supplementation on rumen $\mathrm{NH}_{3}-\mathrm{N}$. However, Fonty and ChaucheyrasDurand (2006) in a detailed review, reported that the effect of yeasts in vivo on ammonia concentrations is highly variable depending on several abiotic (nature of the diet) and biotic (host related and microbial related) factors. The reduced rumen $\mathrm{NH}_{3}-\mathrm{N}$ concentration in the supplemented group may have been due to increased ammonia incorporation into microbial protein (Erasmus et al., 1992), which may be the result of enhanced microbial activity (Wiedmeier et al., 1987; Williams et al., 1991). One other possible reason for the reduced $\mathrm{NH}_{3}-\mathrm{N}$ in the $\mathrm{Y}$ group is that the LY may have reduced the activity of proteolytic rumen bacteria, as was reported in the in vitro study of Chaucheyras-Durand et al. (2005). The increased protozoal population in the Y group had been previously observed in vitro (Carro et al., 1992), in sheep (Mathieu et al., 1996), in Holstein steers (Plata et al., 1994), and in Holstein dairy cows (Dolezal et al., 2005). On the other hand, Doreau and Jouany (1998), in their study on the effect of LY on early lactation dairy cows, found that the total concentration and volume of protozoa did not differ between treatments. The tendency toward higher molar proportion of rumen acetate in the supplemented group 
Table 4. Effect of live yeast culture supplementation (Saccharomyces cereviciae ${ }^{1026}$ ) and BCS at calving on rumen $\mathrm{pH}$, ammonia N, protozoal count, and VFA of dairy cows at d 7 and 21 postpartum

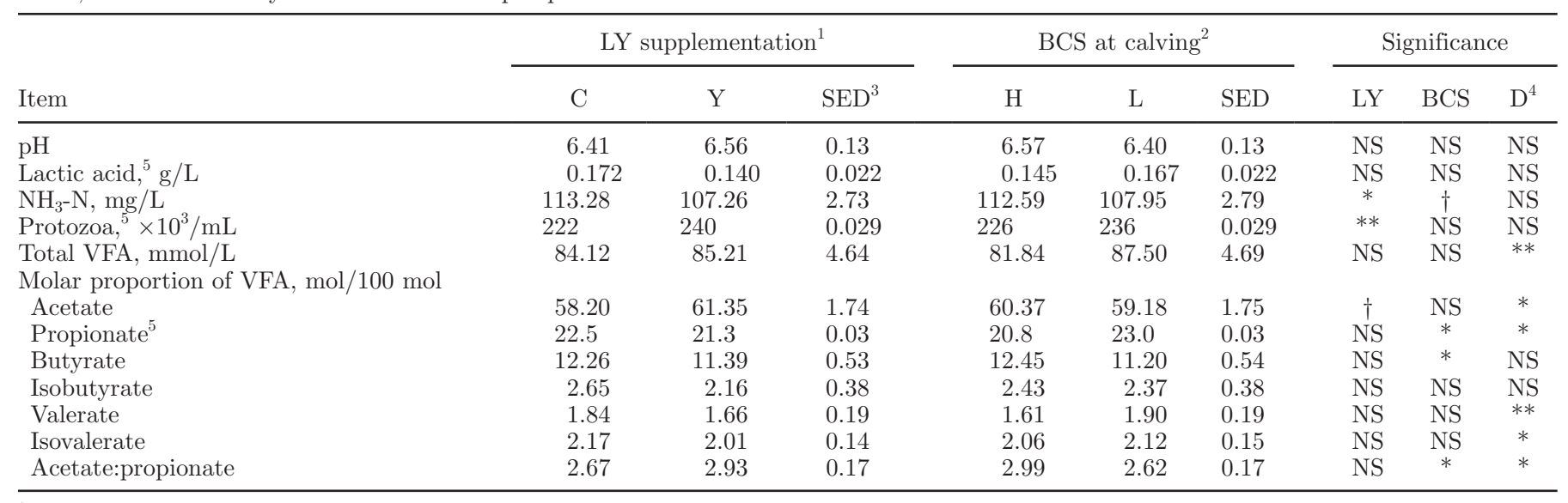

${ }^{1} \mathrm{LY}$ supplementation $=$ live yeast culture supplementation; $\mathrm{C}=$ control; $\mathrm{Y}=$ supplemented.

${ }^{2} \mathrm{BCS}$ at calving: $\mathrm{H}=$ high $\mathrm{BCS}$ at calving; $\mathrm{L}=$ low BCS at calving.

${ }^{3} \mathrm{SED}=$ standard error of differences.

${ }^{4} \mathrm{D}=$ time effect (d 7,21 postpartum).

${ }^{5}$ Level of significance corresponds to transformed variable.

$\dagger P<0.10 ;{ }^{*} P<0.05 ;{ }^{* *} P<0.01$.

was in agreement with previous studies (Wiedmeier et al., 1987; Piva et al., 1993; Zelenak et al., 1994). As suggested by various authors (Wiedmeier et al., 1987; Harrison et al., 1988; Chaucheyras et al., 1995), this increased acetate proportion trend may be related to the stimulating effect of LY on growth or activities of fiber-degrading microorganisms in the rumen.

\section{CONCLUSIONS}

Supplementation with LY had no effect on DMI, milk yield, metabolic status, or body reserve mobilization. However, LY-supplemented cows had increased liver glycogen concentration, rumen protozoal counts, and rumen acetate proportion, and decreased rumen $\mathrm{NH}_{3}-\mathrm{N}$. Cows with lower BCS at calving had lower milk yield but greater DMI, improved metabolic status, reduced liver TAG, reduced TAG:glycogen ratio, and recovered from body condition loss faster than did cows with relatively high BCS at calving. The use of this live yeast product in the transition period did alter some rumen and liver parameters, but did not change milk production, feed intake, or markers of metabolic stress assessed.

\section{ACKNOWLEDGMENTS}

The assistance of staff, technicians, and postgraduate students at University College Dublin Lyons research farm is gratefully appreciated. This work was co-funded by Alltech (Lexington, KY) as part of an Enterprise Ireland innovation partnership.

\section{REFERENCES}

Alshaikh, M. A., M. Y. Alsiadi, S. M. Zahran, H. H. Mogawer, and T. A. Aalshowime. 2002. Effect of feeding yeast culture from different sources on the performance of lactating Holstein cows in Saudi Arabia. Asian-australas. J. Anim. Sci. 15:352-356.

AOAC. 2001. Official Methods of Analysis Vol. I. 17th ed. Association of Official Analytical Chemists, Gaithersburg, MD.

Bines, J. A., and S. V. Morant. 1983. The effect of body condition on metabolic changes associated with intake of food by the cow. Br. J. Nutr. 50:81-89.

Blood, D. C., and O. M. Radostits. 1989. Veterinary Medicine. A Textbook of the Diseases of Cattle, Sheep, Pigs, Goats and Horses. Baillière Tindall, London, UK.

Busato, A., D. Faissler, U. Küpfer, and J. W. Blum. 2002. Body condition scores in dairy cows: Associations with metabolic and endocrine changes in healthy dairy cows. J. Vet. Med. A Physiol. Pathol. Clin. Med. 49:455-460.

Carro, M. D., P. Lebzien, and K. Rohr. 1992. Influence of yeast culture on the in vitro fermentation (Rusitec) of diets containing variable portions of concentrates. Anim. Feed Sci. Technol. 37:209-220.

Carroll, N. V., R. W. Longley, and J. H. Roe. 1956. The determination of glycogen in liver and muscle by use of anthrone reagent. J. Biol. Chem. 220:583-593.

Chaney, A. L., and E. P. Marbach. 1962. Modified reagents for determination of urea and ammonia. Clin. Chem. 8:130-132.

Chaucheyras, F., G. Fonty, G. Bertin, and P. Gouet. 1995. In vitro $\mathrm{H} 2$ utilization by a ruminal acetogenic bacterium cultivated alone or in association with an archaea methanogen is stimulated by a probiotic strain of Saccharomyces cerevisiae. Appl. Environ. Microbiol. 61:3466-3467.

Chaucheyras-Durand, F., S. Masséglia, and G. Fonty. 2005. Effect of the microbial feed additive Saccharomyces cerevisiae CNCM I-1077 on protein and peptide degrading activities of rumen bacteria grown in vitro. Curr. Microbiol. 50:96-101.

Chaucheyras-Durand, F., N. D. Walker, and A. Bach. 2008. Effects of active dry yeasts on the rumen microbial ecosystem: Past, present and future. Anim. Feed Sci. Technol. 145:5-26.

Dawson, K. A. 1993. Current and future role of yeast culture in animal production: A review of research over the last seven years. Page 269 in Biotechnology in the Feed Industry. T. P. Lyons, ed. Alltech Tech. Publ., Nicholasville, KY. 
Dawson, K. A., K. E. Newman, and J. A. Boling. 1990. Effects of microbial supplements containing yeast and lactobacilli on roughagefed ruminal microbial activities. J. Anim. Sci. 68:3392-3398.

Dolezal, P., J. Dolezal, and J. Trinacty. 2005. The effect of Saccharomyces cerevisiae on ruminal fermentation in dairy cows. Czech J. Anim. Sci. 50:503-510.

Doreau, M., and J. P. Jouany. 1998. Effect of a Saccharomyces cerevisiae culture on nutrient digestion in lactating dairy cows. J. Dairy Sci. 81:3214-3221.

Drackley, J. K., M. J. Richard, D. C. Beitz, and J. W. Young. 1992. Metabolic changes in dairy cows with ketonemia in response to feed restriction and dietary 1,3-butanediol. J. Dairy Sci. 75:16221634 .

Edmonson, A. J., I. J. Lean, L. D. Weaver, T. Farver, and G. Webster. 1989. A body condition scoring chart for Holstein dairy cows. J. Dairy Sci. 72:68-78.

Enjalbert, F., J. E. Garrett, R. Moncoulon, C. Bayourthe, and P. Chicoteau. 1999. Effects of yeast culture (Saccharomyces cerevisiae) on ruminal digestion in non-lactating dairy cows. Anim. Feed Sci. Technol. 76:195-206.

Erasmus, L. J., P. M. Botha, and A. Kistner. 1992. Effect of yeast culture supplement on production, rumen fermentation, and duodenal nitrogen flow in dairy cows. J. Dairy Sci. 75:3056-3065.

Erasmus, L. J., P. H. Robinson, A. Ahmadi, R. Hinders, and J. E. Garrett. 2005. Influence of prepartum and postpartum supplementation of a yeast culture and monensin, or both, on ruminal fermentation and performance of multiparous dairy cows. Anim. Feed Sci. Technol. 122:219-239.

European Committee for Standardization. 2008. Animal Feeding stuffs-Isolation and enumeration of yeast probiotic strains. Reference number: prEN15789:2008: E. European Committee for Standardization, Brussels, Belgium.

Feinstein, R., H. Kanety, M. Z. Papa, B. Lunenfeld, and A. Karasik. 1993. Tumor necrosis factor-alpha suppresses insulin-induced tyrosine phosphorylation of insulin receptor and its substrates. J. Biol. Chem. 268:26055-26058.

Fonty, G., and F. Chaucheyras-Durand. 2006. Effects and modes of action of live yeasts in the rumen. Biologia 61:741-750.

Friggens, N. C., J. B. Andersen, T. Larsen, O. Aaes, and R. J. Dewhurst. 2004. Priming the dairy cow for lactation: A review of dry cow feeding strategies. Anim. Res. 53:453-473.

Garnsworthy, P. C., and J. H. Topps. 1982. The effect of body condition of dairy cows at calving on their food intake and performance when given complete diets. Anim. Prod. 35:113-119.

Gillund, P., O. Reksen, Y. T. Grhn, and K. Karlberg. 2001. Body condition related to ketosis and reproductive performance in Norwegian dairy cows. J. Dairy Sci. 84:1390-1396.

Goodall, S. R., and F. M. Byers. 1978. Automated micro method for enzymatic $(+)$ and $(-)$ lactic acid determinations in biological fluids containing cellular extracts. Anal. Biochem. 89:80-86.

Grainger, C., G. D. Wilhelms, and A. A. McGowan. 1982. Effect of body condition at calving and level of feeding in early lactation on milk production of dairy cows. Aust. J. Exp. Agric. Anim. Husb. 22:9-17.

Gröhn, Y., and L. A. Lindberg. 1982. Methodological aspects of the microscopy of bovine liver biopsies. J. Comp. Pathol. 92:567578.

Guedes, C. M., D. Gonçalves, M. A. M. Rodrigues, and A. Dias-daSilva. 2008. Effects of a Saccharomyces cerevisiae yeast on ruminal fermentation and fibre degradation of maize silages in cows. Anim. Feed Sci. Technol. 145:27-40.

Hammon, H. M., G. Sturmer, F. Schneider, A. Tuchscherer, H. Blum, T. Engelhard, A. Genzel, R. Staufenbiel, and W. Kanitz. 2009. Performance and metabolic and endocrine changes with emphasis on glucose metabolism in high-yielding dairy cows with high and low fat content in liver after calving. J. Dairy Sci. 92:1554-1566.

Harrison, G. A., R. W. Hemken, K. A. Dawson, R. J. Harmon, and K. B. Barker. 1988. Influence of addition of yeast culture supplement to diets of lactating cows on ruminal fermentation and microbial populations. J. Dairy Sci. 71:2967-2975.
Hayirli, A., R. R. Grummer, E. V. Nordheim, and P. M. Crump. 2002. Animal and dietary factors affecting feed intake during the prefresh transition period in Holsteins. J. Dairy Sci. 85:3430-3443.

Hoedemaker, M., D. Prange, H. Zerbe, J. Frank, A. Daxenberger, and H. H. D. Meyer. 2004. Peripartal propylene glycol supplementation and metabolism, animal health, fertility, and production in dairy cows. J. Dairy Sci. 87:2136-2145.

Ingvartsen, K. L. 2006. Feeding- and management-related diseases in the transition cow: Physiological adaptations around calving and strategies to reduce feeding-related diseases. Anim. Feed Sci. Technol. 126:175-213.

Ingvartsen, K. L., and J. B. Andersen. 2000. Integration of metabolism and intake regulation: A review focusing on periparturient animals. J. Dairy Sci. 83:1573-1597.

Jordan, E., D. Kenny, M. Hawkins, R. Malone, D. K. Lovett, and F. P. O'Mara. 2006. Effect of refined soy oil or whole soybeans on intake, methane output, and performance of young bulls. J. Anim. Sci. 84:2418-2425.

Kokkonen, T., J. Taponen, T. Anttila, L. Syrjala-Qvist, C. Delavaud, Y. Chilliard, M. Tuori, and A. T. Tesfa. 2005. Effect of body fatness and glucogenic supplement on lipid and protein mobilization and plasma leptin in dairy cows. J. Dairy Sci. 88:1127-1141.

Kung, L. Jr., E. M. Kreck, R. S. Tung, A. O. Hession, A. C. Sheperd, M. A. Cohen, H. E. Swain, and J. A. Z. Leedle. 1997. Effects of a live yeast culture and enzymes on in vitro ruminal fermentation and milk production of dairy cows. J. Dairy Sci. 80:2045-2051.

Kunz, P. L., J. W. Blum, I. C. Hart, H. Bickel, and J. Landis. 1985 Effects of different energy intakes before and after calving on food intake, performance and blood hormones and metabolites in dairy cows. Anim. Sci. 40:219-231.

Lehloenya, K. V., D. R. Stein, D. T. Allen, G. E. Selk, D. A. Jones, M. M. Aleman, T. G. Rehberger, K. J. Mertz, and L. J. Spicer. 2008. Effects of feeding yeast and propionibacteria to dairy cows on milk yield and components, and reproduction. J. Anim. Physiol. Anim. Nutr. (Berl.) 92:190-202.

Marden, J. P., C. Julien, V. Monteils, E. Auclair, R. Moncoulon, and C. Bayourthe. 2008. How does live yeast differ from sodium bicarbonate to stabilize ruminal $\mathrm{pH}$ in high-yielding dairy cows? J. Dairy Sci. 91:3528-3535.

Mathieu, F., J. P. Jouany, J. Senaud, J. Bohotier, G. Bertin, and M. Mercier. 1996. The effect of Saccharomyces cerevisiae and Aspergillus oryzae on fermentations in the rumen of faunated and defaunated sheep; protozoal and probiotic interactions. Reprod. Nutr. Dev. 36:271-287.

McNamara, S., F. P. O'Mara, M. Rath, and J. J. Murphy. 2003. Effects of different transition diets on dry matter intake, milk production, and milk composition in dairy cows. J. Dairy Sci. 86:2397-2408.

Moallem, U., H. Lehrer, L. Livshitz, M. Zachut, and S. Yakoby. 2009. The effects of live yeast supplementation to dairy cows during the hot season on production, feed efficiency, and digestibility. J. Dairy Sci. 92:343-351

Mulligan, F. J., and M. L. Doherty. 2008. Production diseases of the transition cow. Vet. J. 176:3-9.

Mulligan, F. J., L. O'Grady, D. A. Rice, and M. L. Doherty. 2006. A herd health approach to dairy cow nutrition and production diseases of the transition cow. Anim. Reprod. Sci. 96:331-353.

Newbold, C. J., R. J. Wallace, X. B. Chen, and F. M. McIntosh. 1995. Different strains of Saccharomyces cerevisiae differ in their effects on ruminal bacterial numbers in vitro and in sheep. J. Anim. Sci. $73: 1811-1818$.

Nordlund, K. V., and E. F. Garrett. 1994. Rumenocentesis: A technique for collecting rumen fluid for the diagnosis of subacute rumen acidosis in dairy herds. Bovine Pract. 28:109-112.

O'Keefee, M., and J. Sherrington. 1983. Comparison of three methods for determination of urea in compound feed and silage. Analyst (Lond.) 108:1374-1379.

Ohgi, T., S. Kamimura, Y. Minezaki, and M. Takahashi. 2005. Relationship between fat accumulation in the liver and energy intake, milk fat yield and blood metabolites in dairy cows. Anim. Sci. 76:549-557. 
Ohtsuka, H., M. Koiwa, A. Hatsugaya, K. Kudo, F. Hoshi, N. Itoh, H. Yokota, H. Okada, and S.-i. Kawamura. 2001. Relationship between serum TNF activity and insulin resistance in dairy cows affected with naturally occurring fatty liver. J. Vet. Med. Sci. 63:1021-1025.

Piva, G., S. Belladonna, G. Fusconi, and F. Sicbaldi. 1993. Effects of yeast on dairy cow performance, ruminal fermentation, blood components, and milk manufacturing properties. J. Dairy Sci. $76: 2717-2722$.

Plata, F., G. D. Mendoza, J. R. Barcena-Gama, and S. Gonzalez. 1994. Effect of a yeast culture (Saccharomyces cerevisiae) on neutral detergent fiber digestion in steers fed oat straw based diets. Anim. Feed Sci. Technol. 49:203-210.

Porter, M. G., and R. S. Murray. 2001. The volatility of components of grass silage on oven drying and the inter-relationship between drymatter content estimated by different analytical methods. Grass Forage Sci. 56:405-411.

Putnam, D. E., C. G. Schwab, M. T. Socha, N. L. Whitehouse, N. A. Kierstead, and B. D. Garthwaite. 1997. Effect of yeast culture in the diets of early lactation dairy cows on ruminal fermentation and passage of nitrogen fractions and amino acids to the small intestine. J. Dairy Sci. 80:374-384.

Robinson, D. L., C. A. McDonald, K. Hammond, and J. W. Turner. 1992. Live animal measurement of carcass traits by ultrasound: Assessment and accuracy of sonographers. J. Anim. Sci. 70:16671676.

SAS Institute. 2004. SAS User's Guide. SAS Inst. Inc., Cary, NC.

Soder, K. J., and L. A. Holden. 1999. Dry matter intake and milk yield and composition of cows fed yeast prepartum and postpartum. J. Dairy Sci. 82:605-610.

Stockdale, C. R. 2001. Body condition at calving and the performance of dairy cows in early lactation under Australian conditions: a review. Aust. J. Exp. Agric. 41:823-839.

Stockdale, C. R. 2004. Effects of level of feeding of concentrates during early lactation on the yield and composition of milk from grazing dairy cows with varying body condition score at calving. Aust. J. Exp. Agric. 44:1-9.

Thrune, M., A. Bach, M. Ruiz-Moreno, M. D. Stern, and J. G. Linn. 2009. Effects of Saccharomyces cerevisiae on ruminal $\mathrm{pH}$ and mi- crobial fermentation in dairy cows: Yeast supplementation on rumen fermentation. Livest. Sci. 124:261-265.

Tilley, J. M. A., and R. A. Terry. 1963. A two-stage technique for the in vitro digestion of forage crops. Grass Forage Sci. 18:104-111.

Tyrrell, H. F., and J. T. Reid. 1965. Prediction of the energy value of cow's milk. J. Dairy Sci. 48:1215-1223.

Van Soest, P. J., J. B. Robertson, and B. A. Lewis. 1991. Methods for dietary fiber, neutral detergent fiber, and nonstarch polysaccharides in relation to animal nutrition. J. Dairy Sci. 74:3583-3597.

Wang, Z., M. L. Eastridge, and X. Qiu. 2001. Effects of forage neutral detergent fiber and yeast culture on performance of cows during early lactation. J. Dairy Sci. 84:204-212.

Wathes, D. C., N. Bourne, Z. Cheng, G. E. Mann, V. J. Taylor, and M. P. Coffey. 2007. Multiple correlation analyses of metabolic and endocrine profiles with fertility in primiparous and multiparous cows. J. Dairy Sci. 90:1310-1325.

Wiedmeier, R. D., M. J. Arambel, and J. L. Walters. 1987. Effect of yeast culture and Aspergillus oryzae fermentation extract on ruminal characteristics and nutrient digestibility. J. Dairy Sci. 70:2063-2068

Williams, P. E., C. A. Tait, G. M. Innes, and C. J. Newbold. 1991. Effects of the inclusion of yeast culture (Saccharomyces cerevisiae plus growth medium) in the diet of dairy cows on milk yield and forage degradation and fermentation patterns in the rumen of steers. J. Anim. Sci. 69:3016-3026.

Wohlt, J. E., T. T. Corcione, and P. K. Zajac. 1998. Effect of yeast on feed intake and performance of cows fed diets based on corn silage during early lactation. J. Dairy Sci. 81:1345-1352.

Wohlt, J. E., A. D. Finkelstein, and C. H. Chung. 1991. Yeast culture to improve intake, nutrient digestibility, and performance by dairy cattle during early lactation. J. Dairy Sci. 74:1395-1400.

Yoon, I. K., and M. D. Stern. 1996. Effects of Saccharomyces cerevisiae and Aspergillus oryzae cultures on ruminal fermentation in dairy cows. J. Dairy Sci. 79:411-417.

Zelenak, I., D. Jalc, V. Kmet, and P. Siroka. 1994. Influence of diet and yeast supplement on in vitro ruminal characteristics. Anim. Feed Sci. Technol. 49:211-221. 